\title{
REACTIONS OF CYCLOTRIGERMANE WITH P-BENZOQUINONES: OLIGOMERS AND A NOVEL 1,3-CYCLOADDUCT
}

\author{
Bruno Valentin ${ }^{1}$, Annie Castel ${ }^{1}$, Pierre Riviere ${ }^{1}$, Mario Onyszchuk ${ }^{2}$, \\ Anne-Marie Lebuis ${ }^{2}$ and Celine Pearson ${ }^{2}$. \\ 'Laboratoire d'Heterochimie Fondamentale et Appliquee UPRES(A) $n^{\circ} 5069$, Universite Paul \\ Sabatier, 118 Route de Narbonne, 31062 Toulouse Cedex, France \\ ${ }^{2}$ Department of Chemistry, McGill University, 801 Sherbrooke St., West, Montreal, QC, H3A 2K6, \\ Canada
}

\begin{abstract}
Thermolysis of hexamesitylcyclotrigermane in the presence of various derivatives of $p$ benzoquinone are described. A surprising 1,3-cycloadduct was isolated in the case of $\mathrm{p}$ benzoquinone; it is the first example of a 1,3-cycloaddition of a digermene to a quinone followed by a 1,4-H shift. The X-ray crystal structure of the adduct reveals a planar configuration of fused fiveand six-membered rings and a deformation of the heterocycle because of the germanium atoms. Two other p-quinones substituted in ortho positions by aromatic cycles (naphthoquinone and anthraquinone) were used to decrease the fraction of the rearranged cycloadduct and thereby to increase the oligomeric forms.
\end{abstract}

\section{Introduction}

Recently we described the reactions of hexamesitylcyclotrigermane with various $\alpha$ diketones $^{1}$ and showed that they proceed by a pathway involving radicals to give cyclic and polymeric compounds. The mechanism of the addition of carbonyl compounds such as aldehydes or ketones to disilene or germasilene (generated by photolysis of the corresponding trimetalla compounds) has been determined ${ }^{2}$. These authors also proposed the formation of biradical intermediates which gave disproportionation or ring closure. On the other hand, it has been reported that the photolysis of cyclic organosilanes with phenantraquinone gave silylene insertion products by a process involving radicals ${ }^{3}$. We now report reactions of cyclotrigermane with $p$ benzoquinone, $p$-naphthoquinone and $p$-anthraquinone with the objective of determining whether or not they proceed by a similar pathway.

\section{Results and discussion}

When 1,4-benzoquinone was allowed to react with hexamesitylcyclotrigermane ${ }^{4}$, we obtained a mixture of a linear oligomer 2 having one organogermylene unit, a cyclic oligomer $3^{1}$ and a surprising 1,3-cycloadduct 4 , the formation of which was mentioned ${ }^{1}$ but that was not identified.

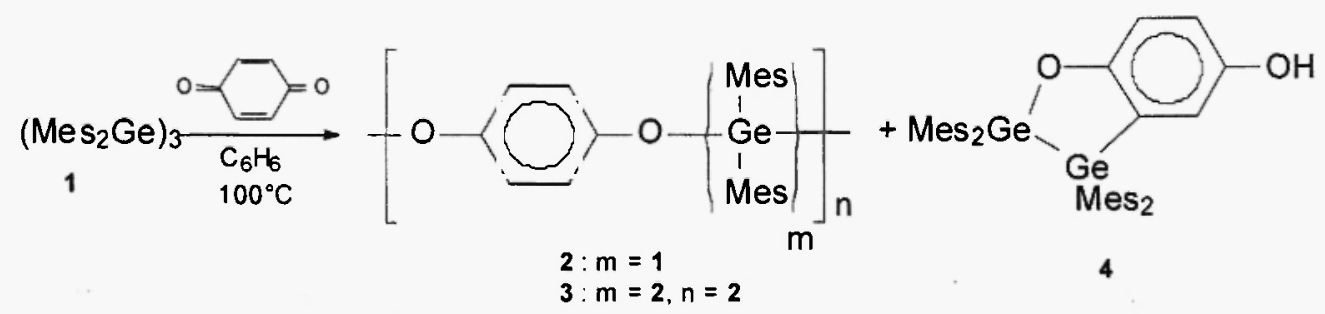

Compound 4.could be extracted from the reaction mixture after several recrystallizations from hexane, petroleum ether and ether, and was obtained pure in a $17 \%$ yield. In its ${ }^{1} \mathrm{H}$ and ${ }^{13} \mathrm{C}$ NMR spectra, the two mesityl groups are not equivalent, as expected from the different environments of the germanium atoms, one attached to an oxygen atom and the other to a carbon atom of the aromatic ring. The ${ }^{1} \mathrm{H}$ NMR spectrum of the aromatic system showed the expected coupling interactions of the three non-equivalent protons. An $\mathrm{X}$-ray crystal structure study of compound 4 confirmed its 1,3-cycloadduct structure as shown by the ORTEP diagram in Figure 1. The two five- and six-membered rings are in the same plane, but the heterocycle is highly distorted. 
The $\mathrm{C}_{56} \mathrm{Ge}_{1} \mathrm{Ge}_{2}$ and $\mathrm{O}_{1} \mathrm{Ge}_{1} \mathrm{Ge}_{2}$ angles are decreased respectively to $87.66(8)^{\circ}$ and $91.09(6)^{\circ}$, whereas $\mathrm{C}_{51} \mathrm{O}_{1} \mathrm{Ge}_{2}$ and $\mathrm{C}_{51} \mathrm{C}_{56} \mathrm{Ge}_{1}$ angles are increased to $120.5(2)$ and 117.8(2). The bond distance $\mathrm{C}_{51}-\mathrm{C}_{56}(1.381(3) \AA)$ is close to that of the normal $\mathrm{C}=\mathrm{C}$ double bond ${ }^{5}$, and the corresponding angles $\mathrm{O}_{1} \mathrm{C}_{51} \mathrm{C}_{56}\left(122.8(3)^{\circ}\right)$ and $\mathrm{C}_{51} \mathrm{C}_{56} \mathrm{Ge}_{1}\left(117.8(2)^{\circ}\right)$ are also very near to the values expected for an $\mathrm{sp}^{-2}$-hybridized $\mathrm{C}$ atom. The bond distance $\mathrm{Ge}_{2}-\mathrm{O}_{1}(1.828(2) \AA), \mathrm{Ge}_{1}-\mathrm{C}_{56}$ $(1.956(3) \AA)$ and $\mathrm{Ge}_{1}-\mathrm{Ge}_{2}(2.4611(5) \AA)$ are consistent with literature values ${ }^{6}$.

The germanium atoms are distorted tetrahedral. The hydroxy hydrogen is disordered over the two possible orientations since both are geometrically suitable. In each case the $\mathrm{OH}$ group forms a twelve-membered ring in which there are disordered solvent molecules (hexane in this case) (Figure 2). Selected bond lengths and bond angles are displayed in Table 1, and crystallographic data are given in Table 2.

The same reaction with 1,4-naphthoquinone and anthraquinone, which does not have a hydrogen atom in the ortho position of the quinonic ring, gave only the oligomeric forms 5 and $\mathbf{6}$ (eq. 2):

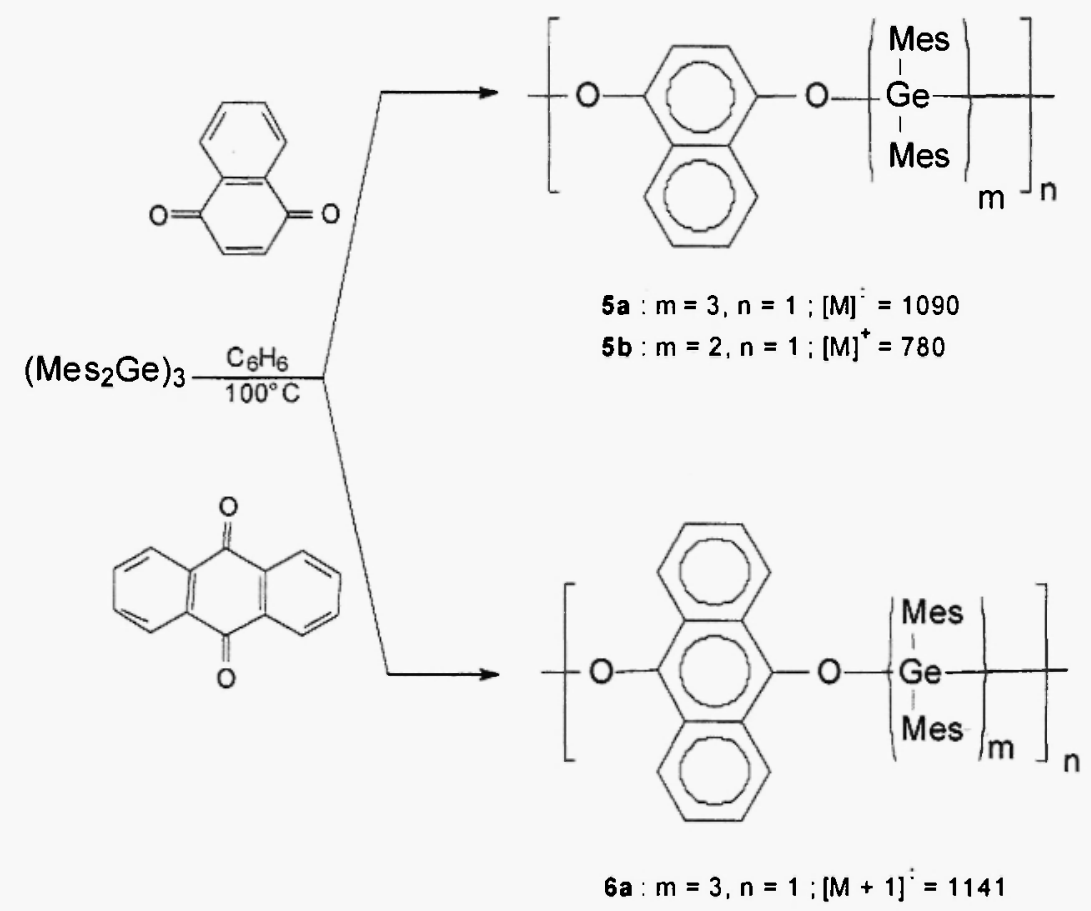

Proton NMR measurements indicated a predominant 1:2 composition of quinonic and organogermanium units. In the both cases, minor amounts of the trigermacycloadducts $\mathbf{5 a}$ and $\mathbf{6 a}$, were detected by mass spectrometry $\left(\mathrm{DCl} \mathrm{CH}_{4}\right.$ or $\mathrm{NH}_{3}$ ) but the digermylated derivative $\mathbf{5} \mathbf{b}$ was found only in the case of the naphthoquinone. Although all these compounds are very soluble in organic solvents, it would be very difficult to extract each macrocycle from the reaction mixture.

The formation of trigermylated macrocycles can be explained by an initial homolytic cleavage of one of the germanium-germanium bonds followed by the condensation of the biradical intermediate onto the quinonic species. Such a cleavage of just one $\mathrm{Ge}-\mathrm{Ge}$ bond to give a trigermylated adduct has previously been observed in the reaction of hexa-t-butylcyclotrigermane with iodine ${ }^{7}$. The subsequent release of the dimesityl germylene group by $\alpha$-monoelectronic elimination [8] should give the biradical di- or mono-metallated intermediates 8 and 9 that rapidly form oligomers 3 and 2 (Scheme 1).

To yield compound 4 , the rearrangement of the biradical intermediate 8 by an elimination of $\mathrm{H}^{\prime}$ from the aromatic ring seems unlikely. In this case an ionic pathway should be considered. Cyclotrigermanes are well known to generate transient digermene by photolysis or thermolysis ${ }^{9.10}$ and a zwitterionic form 10 can be envisaged (Scheme 2) for the intermediate adduct of the digermene and quinones. 


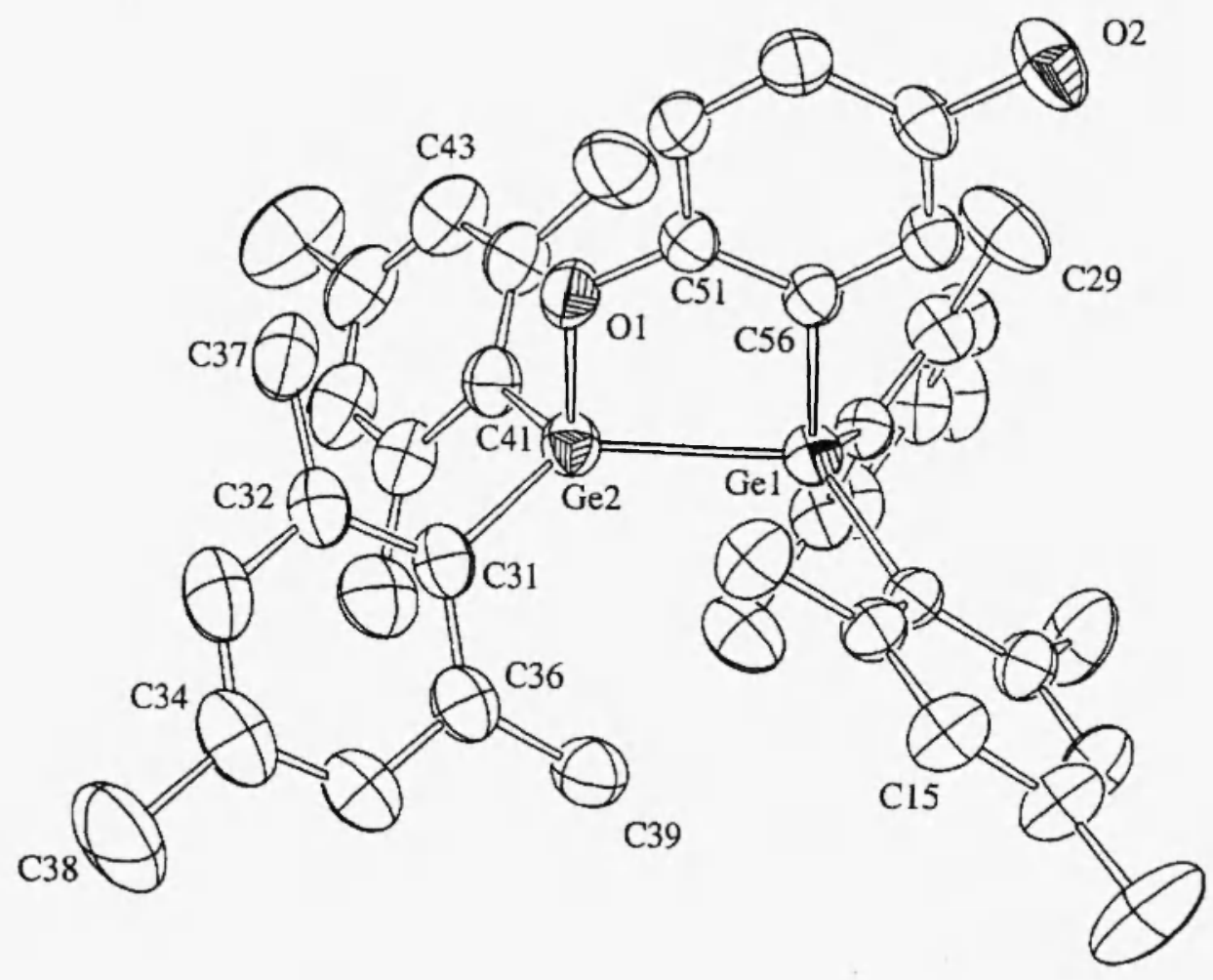

Figure 1: ORTEP drawing of 4. Hydrogen atoms are omitted for clarity.

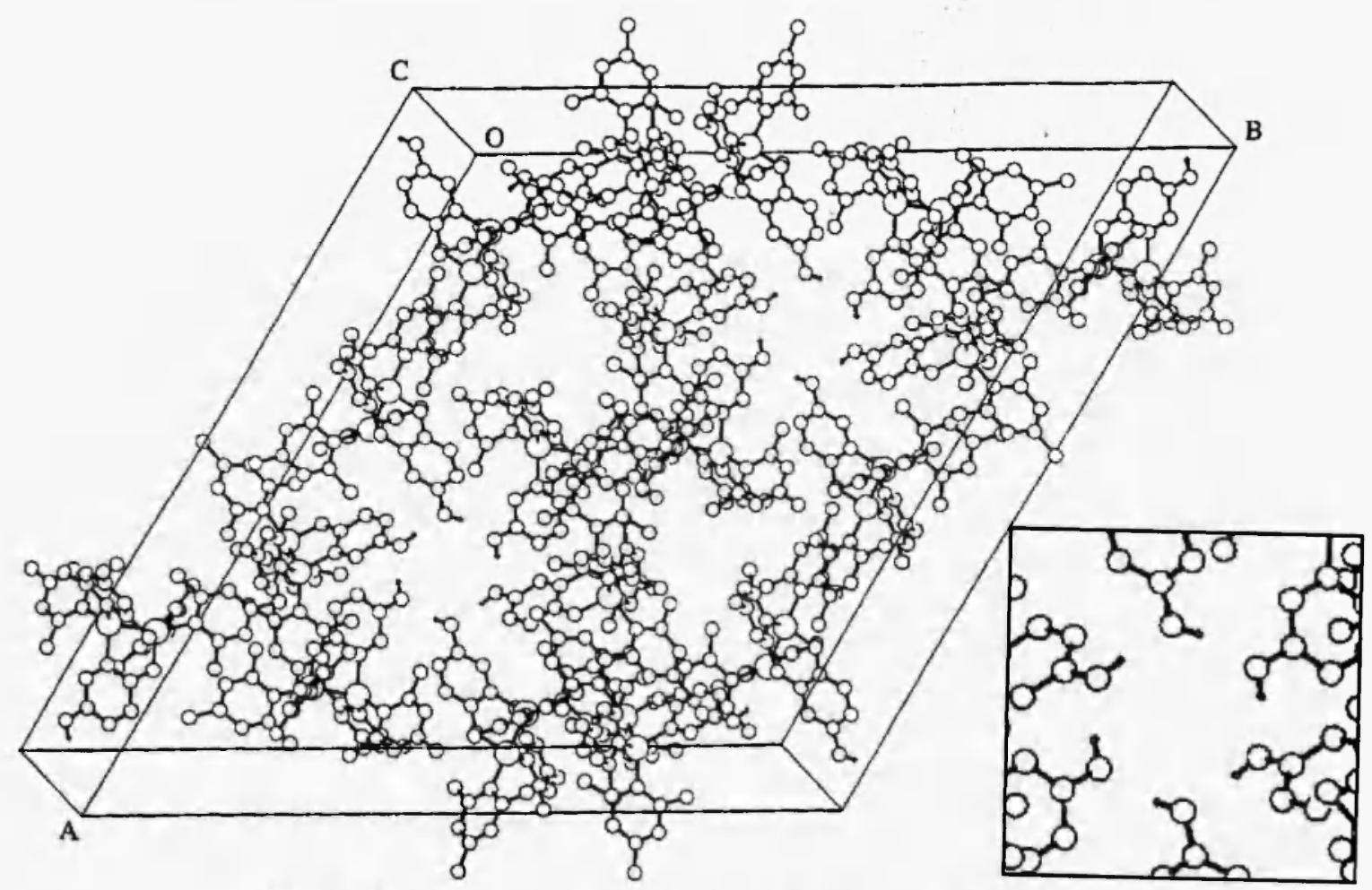

Figure 2: Arrangement of units of 4 to form six-membered rings. 
Table 1: Selected Bond Lengths $(\AA)$ and Bond Angles (deg) of 4 Bond Lengths

\begin{tabular}{cccc}
\hline $\mathrm{Ge}_{1} \mathrm{Ge}_{2}$ & $2.461(5)$ & $\mathrm{Ge}_{1} \mathrm{C}_{56}$ & $1.956(3)$ \\
$\mathrm{O}_{1} \mathrm{Ge}_{2}$ & $1.828(2)$ & $\mathrm{Ge}_{1} \mathrm{C}_{21}$ & $1.983(3)$ \\
$\mathrm{O}_{1} \mathrm{C}_{51}$ & $1.374(3)$ & $\mathrm{C}_{51} \mathrm{C}_{56}$ & $1.381(3)$ \\
$\mathrm{Ge}_{2} \mathrm{C}_{41}$ & $1.988(3)$ & $\mathrm{C}_{54} \mathrm{O}_{2}$ & $1.394(3)$ \\
$\mathrm{Ge}_{2} \mathrm{C}_{31}$ & $1.967(3)$ & $\mathrm{O}_{2} \mathrm{H}_{2 \mathrm{a}}$ & 0.820 \\
$\mathrm{Ge}_{1} \mathrm{C}_{11}$ & $1.987(3)$ & $\mathrm{O}_{2} \mathrm{H}_{2 b}$ & 0.820 \\
\multicolumn{5}{c}{ Bond Angles } \\
\hline $\mathrm{C}_{51} \mathrm{O}_{1} \mathrm{Ge}_{2}$ & $120.50(2)$ & $\mathrm{C}_{56} \mathrm{Ge}_{1} \mathrm{C}_{11}$ & $105.94(11)$ \\
$\mathrm{C}_{51} \mathrm{C}_{56} \mathrm{Ge}_{1}$ & $117.80(2)$ & $\mathrm{C}_{54} \mathrm{O}_{2} \mathrm{H}_{2 b}$ & 109.47 \\
$\mathrm{O}_{1} \mathrm{Ge}_{2} \mathrm{Ge}_{1}$ & $91.09(6)$ & $\mathrm{O}_{1} \mathrm{Ge}_{2} \mathrm{C}_{31}$ & $101.70(10)$ \\
$\mathrm{C}_{56} \mathrm{Ge}_{1} \mathrm{Ge}_{2}$ & $87.66(8)$ & $\mathrm{C}_{31} \mathrm{Ge}_{2} \mathrm{C}_{41}$ & $109.53(12)$ \\
$\mathrm{C}_{41} \mathrm{Ge}_{2} \mathrm{O}_{1}$ & $103.40(11)$ & $\mathrm{O}_{1} \mathrm{C}_{51} \mathrm{C}_{52}$ & $116.10(3)$ \\
$\mathrm{O}_{1} \mathrm{C}_{51} \mathrm{C}_{56}$ & $122.80(3)$ & $\mathrm{C}_{55} \mathrm{C}_{54} \mathrm{O}_{2}$ & $119.00(3)$ \\
& & & \\
\hline
\end{tabular}

Then the cycloaddition induced by the germylcation might lead, after migration of a proton, to the expected 1,3-cycloadduct 4 . This is the first example of a cycloaddition reaction between a digermene and a paraquinone.

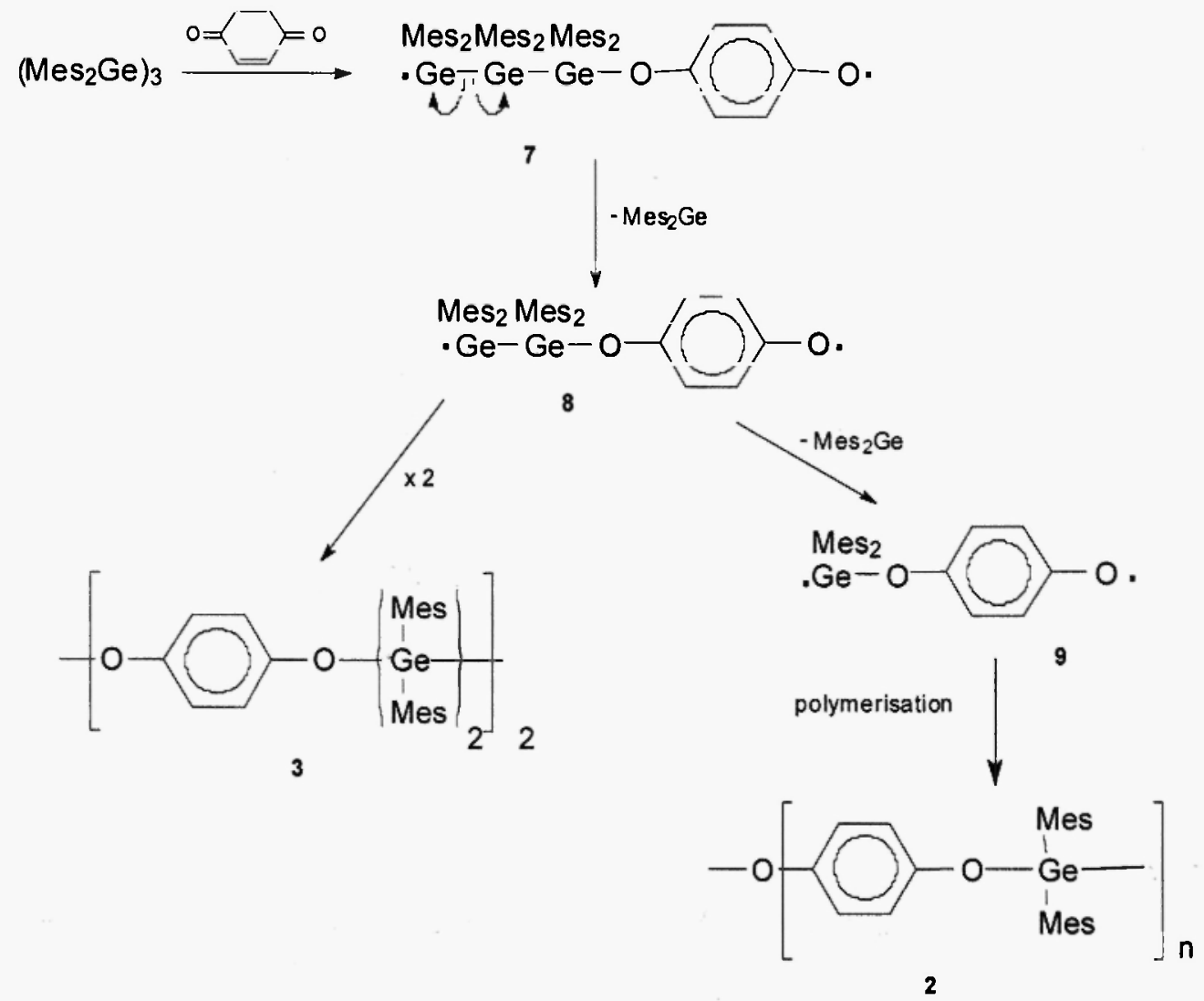

\section{Experimental}

Scheme 1

All reactions were performed under a dry nitrogen atmosphere using, standard Schlenk techniques. Compounds were characterized by the usual analytical techniques: ${ }^{4} H$ NMR, A.C.80 or 200 Bruker; ${ }^{13} \mathrm{C}\{$ 'H\} NMR, A.C.200 Bruker; IR, Perkin-Elmer 1600 F.T.; Mass spectra, Ribermag R 
$1010\left(\mathrm{Cl} / \mathrm{CH}_{4}\right)$, API 100 Perkin-Elmer SCIEX (ES). Elemental analyses were done by the Centre de Microanalyse de l'Ecole Nationale Superieure de Chimie de Toulouse.

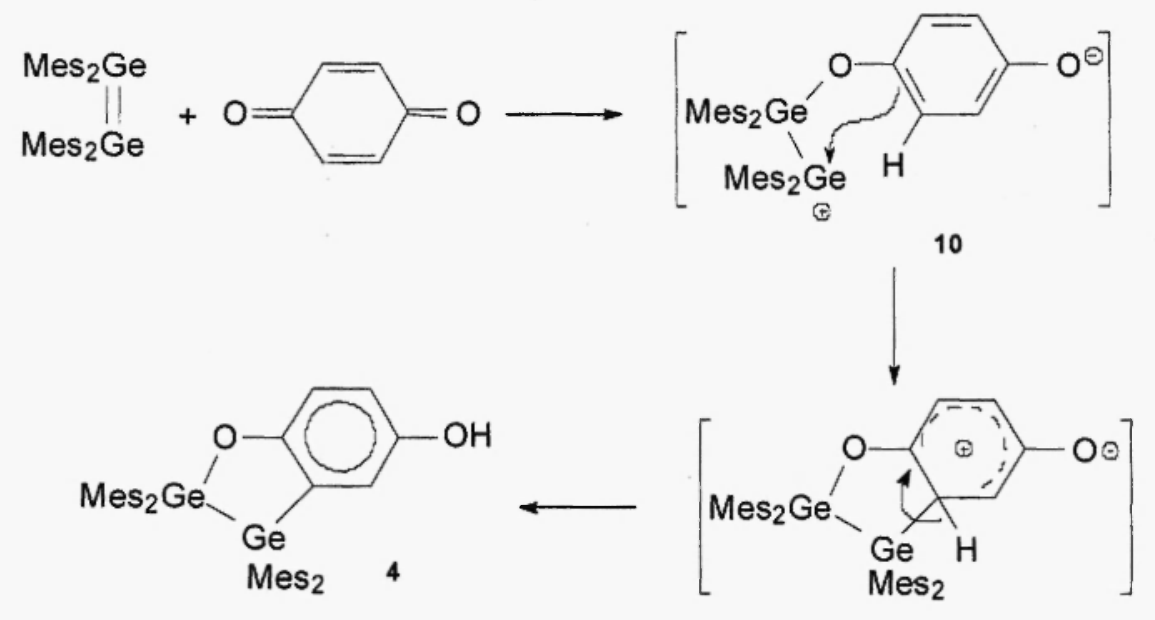

Scheme 2

Thermolysis of 1 in presence of parabenzoquinone:

A solution of $1^{-}(0.28 \mathrm{~g}, 0.3 \mathrm{mmol})$ and parabenzoquinone $(0.11 \mathrm{~g}, 1 \mathrm{mmol})$ in $3 \mathrm{~mL}$ of benzene was heated at $100^{\circ} \mathrm{C}$ for $3 \mathrm{~d}$ in a Carius tube. The benzene was evaporated in vacuo and the residue extracted with hot hexane. The mixture was filtered. After $2 \mathrm{~d}$ at $20^{\circ} \mathrm{C}$, brown crystals were formed in the filtrate; they were isolated by decantation and identified as 4: $0.05 \mathrm{~g}$ (yield 17 $\%$ ), mp 160-162 ${ }^{\circ} \mathrm{C} .{ }^{1} \mathrm{H}$ NMR $\left(\mathrm{C}_{6} \mathrm{D}_{6}\right) 200 \mathrm{MHz} \delta: 2.01\left(\mathrm{~s}, 6 \mathrm{H}, \mathrm{p}-\mathrm{CH}_{3}\right)$ and $2.03\left(\mathrm{~s}, 6 \mathrm{H}, \mathrm{p}-\mathrm{CH}_{3}\right), 2.30$ $\left(\mathrm{s}, 12 \mathrm{H}, \mathrm{o}-\mathrm{CH}_{3}\right)$ and $2.44\left(\mathrm{~s}, 12 \mathrm{H}_{1} \mathrm{o}-\mathrm{CH}_{3}\right), 3.43(\mathrm{~s}, 1 \mathrm{H}, \mathrm{OH}), 6.57\left(\mathrm{~s}, 4 \mathrm{H}_{1} \mathrm{C}_{6} \mathrm{H}_{2}\right)$ and $6.60\left(\mathrm{~s}, 4 \mathrm{H}_{1}\right.$ $\mathrm{C}_{6} \mathrm{H}_{2}$ ), 6.61 (dd, $\left.{ }_{1} \mathrm{~J}=3 \mathrm{~Hz},{ }^{3} \mathrm{~J}=8.5 \mathrm{~Hz}, 1 \mathrm{H}, \mathrm{C}_{6} \mathrm{H}_{3}\right), 6.85\left(\mathrm{~d},{ }^{3} \mathrm{~J}=3 \mathrm{~Hz}_{1} 1 \mathrm{H}_{1} \mathrm{C}_{6} \mathrm{H}_{3}\right), 6.99\left(\mathrm{~d}^{3} \mathrm{~J}=8.5\right.$ $\left.\mathrm{Hz}, 1 \mathrm{H}, \mathrm{C}_{6} \mathrm{H}_{3}\right) .{ }^{13} \mathrm{C}\left\{{ }^{1} \mathrm{H}\right\}$ NMR $\left(\mathrm{C}_{6} \mathrm{D}_{6}\right) \delta: 20.89$ and $20.92\left(\mathrm{p}-\mathrm{CH}_{3}\right), 24.58$ and $25.56\left(\mathrm{o}-\mathrm{CH}_{3}\right), 129.41$, $129.49,136.04,137.89,138.66,138.76,143.65,144.23: \mathrm{C}_{6} \mathrm{H}_{2} ; 118.85,118.97,121.63,130.32$, 148.77, 159.56: $\mathrm{C}_{6} \mathrm{H}_{3} . \mathrm{MS}\left(\mathrm{Cl} / \mathrm{CH}_{4}\right): 759(\mathrm{M}+29), 730(\mathrm{M}), 611(\mathrm{M}-\mathrm{Mes}) . \mathrm{IR}: 3213 \mathrm{~cm}^{-4}(\mathrm{~V} \mathrm{OH})$. Anal. calcd for $\mathrm{C}_{42} \mathrm{H}_{48} \mathrm{Ge}_{2} \mathrm{O}_{2}, \mathrm{C}_{6} \mathrm{H}_{14}: \mathrm{C}, 70.64 ; \mathrm{H}, 7.66$. Found: $\mathrm{C}, 70.44 ; \mathrm{H}, 7.60 \%$. Crystals suitable for X-ray study were obtained by recrystallization from an ether / petroleum ether mixture $(2 / 1)$. The filtrate when was analyzed by mass spectrometry revealed the presence of 3 (ES MS: $=1415\left(\mathrm{M}-3 \mathrm{CH}_{3}\right)$. It was impossible to isolate 3 in pure form. The precipitate was identified as 2 [1]. Crystal and Experimental Data for 4:

The structure was solved by direct methods using SHELXS96 (Sheldrick, 1996) and difmap synthesis using SHELXL96 (Sheldrick, 1996). All non-hydrogen atoms are anisotropic, and hydrogen atoms are isotropic. Hydrogen atoms were calculated at idealized positions using a riding model with different $\mathrm{C}-\mathrm{H}$ distances for each type of hydrogen.

The isotropic displacement factors, $U$-iso-, were adjusted to $50 \%$ higher value of the bonded carbon atom (methyl) and $20 \%$ higher (others). The hydroxy hydrogen was calculated and it is disordered over the two possible orientations since both are geometrically suitable. In each case, the $\mathrm{OH}$ group forms a six-membered ring through $\mathrm{H}$-bonds. This ring formation results in the construction of a channel in which there are disordered solvent molecules. The location of these molecules in the channel was precluded by the high degree of disorder. The PLATON program CALC SQUEEZE was used to subtract the solvent contribution from the observed data. The identity of the solvent (hexane) was deduced from NMR and elemental analyses. This attribution also agrees with the geometry of the channels. Crystallographic data have been deposited at the Cambridge Crystallographic Data Centre, CCDC 135142, deposit@ccdc.cam.ac.uk.

Thermolysis of 1 in the presence of $p$-naphthoquinone:

A solution of $1(0.28 \mathrm{~g}, 0.3 \mathrm{mmol})$ and p-naphthoquinone $(0.07 \mathrm{~g}, 0.45 \mathrm{mmol})$ in $1.5 \mathrm{~mL}$ of benzene was heated at $100^{\circ} \mathrm{C}$ for $16 \mathrm{~h}$ in a Carius tube. The benzene was evaporated in vacuo and the residue (highly soluble in common solvents) was analyzed and identified as a mixture of oligomeric forms 5: ' $\mathrm{H}$ NMR $\left(\mathrm{CDCl}_{3}\right) \delta$ : 1.92-2.65 (m, $18 \mathrm{H}, \mathrm{p}-\mathrm{CH}_{3}$ and $\left.0-\mathrm{CH}_{3}\right), 6.63\left(\mathrm{~s}, 8 \mathrm{H}_{1} \mathrm{C}_{6} \mathrm{H}_{2}\right)_{1}$ $6.80-7.35\left(\mathrm{~m}, 6 \mathrm{H}, \mathrm{C}_{10} \mathrm{H}_{6}\right)$. Mass spectra showed the presence of $5 \mathrm{a}$ and $5 \mathrm{~b}: \mathrm{MS}\left(\mathrm{Cl} / \mathrm{CH}_{4}\right): 5 \mathrm{a}$ : 1090 (M), 5b: 780 (M). 
Table 2: Data for the $X$-ray crystal structure analysis of 4

\begin{tabular}{|c|c|}
\hline $\begin{array}{c}\text { Crystal size (mm) } \\
\text { formula } \\
\text { Fw } \\
\text { Crystal color / shape } \\
\text { Crystal System } \\
\text { Space Group } \\
\text { a }(\AA) \\
\mathrm{b}(\AA) \\
\mathrm{c}(\AA) \\
\beta\left(^{\circ}\right) \\
V\left(\AA^{3}\right) \\
Z \\
\mathrm{dc}\left(\mathrm{g} \mathrm{cm}^{-3}\right) \\
\mu\left(\mathrm{mm}^{-1}\right) \\
\lambda(\AA) \\
\mathrm{F}(000) \\
\theta \text { range }\left(^{\circ}\right) \\
\text { No reflections measured } \\
\text { No independant reflections }\left(\mathrm{R}_{\text {int }}\right) \\
\text { Trans. range } \\
h \text { range } \\
\mathrm{k} \text { range } \\
\text { I range } \\
\mathrm{R}_{1} \text { (obs / all data) } \\
\text { WR } \mathrm{R}_{2} \text { (obs / all data) } \\
\text { No parameters } \\
\text { No of restraints }\end{array}$ & $\begin{array}{c}.14 \times 0.14 \times 0.08 \\
\mathrm{C}_{42} \mathrm{H}_{48} \mathrm{Ge}_{2} \mathrm{O}_{2}, \mathrm{C}_{6} \mathrm{H}_{14} \\
816.20 \\
\text { Colourless / block } \\
\text { Trigonal } \\
\mathrm{R}-3 \\
36.483(9) \\
36.483(9) \\
17.583(5) \\
90 \\
20268(8) \\
18 \\
1.204 \\
1.869 \\
1.54056 \\
6840 \\
2.42 \text { to } 69.90 \\
41656 \\
8562 \\
0.57 \text { to } 0.90 \\
-45 \text { to } 45 \\
-44 \text { to } 44 \\
-21 \text { to } 21 \\
0.0353 / 0.0668 \\
0.0640 / 0.0688 \\
428 \\
0\end{array}$ \\
\hline
\end{tabular}

Thermolysis of 1 in the presence of p-anthraquinone:

A solution of $1(0.28 \mathrm{~g}, 0.3 \mathrm{mmol})$ and $\mathrm{p}$-anthraquinone $(0.09 \mathrm{~g}, 0.45 \mathrm{mmol})$ in $1.5 \mathrm{~mL}$ of benzene was heated at $100^{\circ} \mathrm{C}$ for $3 \mathrm{~d}$ in a Carius tube. The benzene was evaporated in vacuo and the residue (highly soluble in common solvents) was analyzed and identified as a mixture of oligomeric forms 6: ' $\mathrm{H}$ NMR $\left(\mathrm{CDCl}_{3}\right) \delta$ : $1.85-2.85\left(\mathrm{~m}, 18 \mathrm{H}, \mathrm{p}-\mathrm{CH}_{3}\right.$ and $\left.\mathrm{o}-\mathrm{CH}_{3}\right), 6.80\left(\mathrm{~s}, 8 \mathrm{H}, \mathrm{C}_{6} \mathrm{H}_{2}\right)$, 7.50-8.54 (m, $\left.8 \mathrm{H}, \mathrm{C}_{14} \mathrm{H}_{8}\right)$. Mass spectra showed the presence of $6 \mathrm{a}: \mathrm{MS}\left(\mathrm{Cl} / \mathrm{CH}_{4}\right): 1141(\mathrm{M}+1)$.

\section{References}

1. B. Valentin, A. Castel, P. Riviere, M. Mauzac, M. Onyszchuk, A.M. Lebuis, Heteroatom Chem., 10, 1999, 125.

2. C.E. Dixon, W.D. Hughes, K.M. Baines, J. Am. Chem. Soc., 120, 1998, 11049.

3. M. Kako, M. Ninomiya, Y. Nakadaira, J. Chem. Soc. Chem. Commun., 1997, 1373.

4. T. Tsumuraya, Y. Kabe, W. Ando, J. Organomet. Chem., 482, 1994, 131.

5. A.J. Gordon, R.A. Ford, 'The Chemist's Companion', John Wiley and Sons, New-York, 1972.

6. K.M. Baines, W.G. Stibbs, Coord. Chem. Rev. 145, 1995, 57.

7. M. Weidenbruch, A. Hagedorn, K. Peters, H.G. Von Schenering, Angew. Chem. Int. Ed. Engl., 34, 1995, 1085.

8. P. Riviere, A. Castel, J. Satge, D. Guyot, J. Organomet. Chem., 264, 1984, 193.

9. T. Tsumuraya, S.A. Batcheller, S. Masamune, Angew. Chem. Int. Ed. Engl., 30, 1991, 902.

10. K.M. Baines, W.G. Stibbs, Adv. Organomet. Chem., 39, 1996, 275.

Received: September 20, 1999 - Accepted: October 5, 1999 Accepted in revised camera-ready format: October 8, 1999 